\title{
METABOLIC CHARACTERIZATION AND OIL PROFILE OF SUNFLOWER CULTIVARS CULTIVATED WITH INCREASING NITROGEN DOSES
}

\author{
CARACTERIZAÇÃO METABÓLICA E PERFIL DO ÓLEO DE CULTIVARES DE \\ GIRASSOL CULTIVADOS SOB DOSES CRESCENTES DE NITROGENNIO
}

\section{Janiélio Gonçalves da ROCHA ${ }^{1}$; Luiziene Soares ALVES ${ }^{2}$; Orlando Carlos Huertas TAVARES ${ }^{3}$; Elvia Mariam Lis Martinez STARK ${ }^{3}$; Manlio Silvestre FERNANDES ${ }^{3}$; Rosane Nora CASTRO ${ }^{4}$; André Marques dos SANTOS ${ }^{5^{*}}$; Sonia Regina de $\mathrm{SOUZA}^{3}$ (in memoriam)}

1. Programa de Pós-Graduação em Produção Vegetal, Centro de Ciências e Tecnologias Agropecuárias, Universidade Estadual do Norte Fluminense Darcy Ribeiro - UENF, Campos dos Goytacazes, RJ, Brasil. janieliogr@yahoo.com.br; 2. Programa de Pós-Graduação em Química, Universidade Federal Rural do Rio de Janeiro - UFRRJ, Seropédica, RJ, Brasil; 3. Departamento de Solos, Lab. de Nutrição Mineral de Plantas, Universidade Federal Rural do Rio de Janeiro - UFRRJ, Seropédica, RJ, Brasil; 4. Departamento de Química Orgânica, UFRRJ, Seropédica, RJ, Brasil; 5. Departamento de Bioquímica, UFRRJ, Seropédica, RJ, Brasil. *amarques@ufrrj.br.

\begin{abstract}
Sunflower (Helianthus annuus L.) has great economic importance due to its oil yield and quality. Among the factors influencing these parameters, nitrogen fertilization stands out. In this study we evaluated the effect of different $\mathrm{N}$-urea doses $\left(0,10,30,50,90,130 \mathrm{~kg} \mathrm{~N}^{-u r e a ~ h a} \mathrm{~h}^{-1}\right)$ at planting and 30 days after emergency on soluble fractions, oil profile and yield of three sunflower cultivars (BRS324, Catissol 01 and Neon). Plants were harvested at the flowering stage for metabolic study, and at the end of the cycle for oil extraction and characterization. The Catissol 01 genotype presented the highest $\mathrm{N}^{-\mathrm{NO}_{3}}{ }^{-}$accumulation capacity, mainly in the stem. The Neon genotype presented the highest achene production at 30 and $50 \mathrm{~kg} \mathrm{~N} \mathrm{ha}^{-1}$. Oleic oil had the highest yield, with the Catissol 01 and Neon cultivar standing out. Among the cultivars, Catissol 01 is economically more suitable for biofuel production, when cultivated at $50 \mathrm{~kg} \mathrm{~N}^{-1}$ since higher $\mathrm{N}$ doses did not result in increased oil yield.
\end{abstract}

KEYWORDS: Biofuel. Helianthus annuus L. Oilseed.

\section{INTRODUCTION}

Nitrogen $(\mathrm{N})$, besides being a limiting factor for plant growth, has also been related to production o achenes and oil in sunflower species. Depending on the evaluated genotype, Zagonel and Mundstock (1991) found that oil content decreased when $\mathrm{N}$ levels increased $\left(120 \mathrm{~kg} \mathrm{ha}^{-1}\right)$. Rasool, Hassan and Jahangir (2013) reported grain and oil production increases related to high $\mathrm{N}$ doses, but oil content in the grains decreased. Abdel-Motagally and Osman (2010) observed the influence of $\mathrm{N}$ on several sunflower plant parameters, among them, 100-grain weight and grain and oil yield per plant.

Sunflower oil has high quality for human consumption and use as biodiesel feedstock (LAZZAROTTO; ROESSING; MELLO, 2005). Sunflower oil is rich in unsaturated fatty acids (more than $80 \%$ overall), with linoleic acid being the most abundant (60\%) (MATT et al., 2001). Despite the possibility of use for purposes other than food, it is little used by the non-food sectors due to its limited quantity and high price compared to soybean and other oils (SKORIC; SAKAC; DEMURIN, 2015). However, demand for vegetable oils has been growing due to search for renewable energy alternatives. In this context, sunflower is a viable alternative for producing good quality oil on a large scale (ZOBIOLE et al., 2010).

The use of oils with unsaturated chains such as sunflower oil is relevant for the biodiesel industry, since these oils have less propensity for solidification (KNOTHE, 2008). According to Ramos et al. (2003), biodiesel stability is affected by fatty acid type and content in vegetable oil.

In addition to the genotype and nutrient availability, several environmental factors can influence the fatty acid content of sunflower oil, such as crop location, soil type, precipitation and temperature (SKORIC; SAKAC; DEMURIN, 2015). Thus, it is important to carry out studies to characterize particularities of genotype, as well as performing appropriate $\mathrm{N}$ management to improve sunflower oil quality and profitability. This study evaluated the effect of increasing $\mathrm{N}$ doses on oil quality and yield of three sunflower cultivars, as well as the influence on metabolism and soluble fractions $\left(\mathrm{N}-\mathrm{NO}_{3}{ }^{-}, \mathrm{N}-\mathrm{NH}_{4}{ }^{+}\right.$, soluble $\mathrm{N}$-amino and soluble sugars). 


\section{MATERIALS AND METHODS}

The experiment was carried out at the Department of Soil Science of Rio de Janeiro Federal Rural University (UFRRJ) located at geographic coordinates $43^{\circ} 41^{\prime} \mathrm{W}$ and $22^{\circ} 45^{\prime} \mathrm{S}$ and elevation of $39 \mathrm{~m}$. The climate according to the Köppen classification is Aw, characterized as tropical climate with dry winter. The soil (Argisol) was first prepared by plowing $(20-30 \mathrm{~cm})$ followed by two harrowing. Fertilization at sowing was manually performed based on soil analysis (Table 1), carried out at the Soil Fertility Laboratory of UFRRJ, with application of $40 \mathrm{~kg} \mathrm{ha}^{-1}$ potassium (potassium chloride, $46 \% \mathrm{~K}$ ) and $60 \mathrm{~kg} \mathrm{ha}^{-1}$ phosphorus (super simple, 20\% P) below and beside the seeds. The BRS324, Catissol 01 and Neon
ROCHA, J. G. et al.

cultivars were employed. Three to four seeds were sown per hole, spaced at $0.25 \mathrm{~m} \times 0.50 \mathrm{~m}$. The plants were thinned, one per hole 20 days after emergence (DAE).

A completely randomized experimental design with four replicates in factorial arrangement ( $6 \mathrm{~N}$ doses $\mathrm{x} 3$ cultivars) was used. According to the Tukey test at 5\%, different treatments of a qualitative nature were compared (cultivars), as well as regression test for the quantitative one ( $\mathrm{N}$ doses). For this purpose, we selected mathematical models presenting the best significance levels and the highest determination coefficient $\left(\mathrm{R}^{2}\right)$. The $\mathrm{R}$ software was used, and correlation analyses were performed using the corrplot package (WEI; SIMKO, 2017).

Table 1. Chemical analysis $(0.20 \mathrm{~cm}$ deep) of the argisol sample located at the UFRRJ experimental field, before planting the three sunflower cultivars (Neon, Catissol 01 and BRS324).

\begin{tabular}{|c|c|c|c|c|c|c|c|}
\hline \multirow{3}{*}{$\mathrm{pH}\left(\mathrm{H}_{2} \mathrm{O}\right)$} & \multicolumn{4}{|c|}{ Soil elemental concentration } & & & \\
\hline & \multicolumn{4}{|c|}{$\mathrm{cmol}_{\mathrm{c}} \mathrm{dm}^{-3}$} & \multicolumn{3}{|c|}{$\mathrm{mg} \mathrm{dm}{ }^{-3}$} \\
\hline & $\mathrm{AL}^{3+}$ & $\mathrm{Ca}^{2+}$ & $\mathrm{Mg}^{2+}$ & $\mathrm{H}+\mathrm{AL}^{+3}$ & $\mathrm{~K}$ & $\mathrm{Na}$ & $\mathrm{P}$ \\
\hline 5.6 & 0.0 & 2.8 & 1.0 & 3.6 & 29.0 & 0.0 & 11.0 \\
\hline
\end{tabular}

Eight plants per plot were grown (four cultivated until achene production for oil extraction and analysis and the other four collected at the flowering stage. The fourth leaf from apex to base of each plant, petiole, and stem were harvest to soluble fraction analysis. Samples of fresh material, weighing $0.5 \mathrm{~g}$, were separated and stored in ethanol $(80 \%)$, and after the alcoholic extraction, chloroform partitioning was carried out. The extracts obtained were analyzed to measure the following soluble fractions: $\mathrm{N}-\mathrm{NO}_{3}{ }^{-}$(CATALDO et

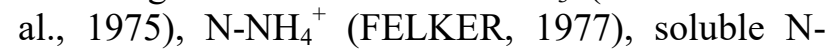
amino (YEMM; COCKING, 1955), and soluble sugars (YEMM; WILLIS, 1954). N-total analysis (TEDESCO et al., 1995) in dry plant material was also performed. Urea treatments (reported in Table 2) at $30 \mathrm{DAE}$ in each plot were applied. At the end of the cycle, grains were dried and weighed. Sunflower oil extraction was carried out using hexane in a Soxhlet apparatus (YANIV et al., 1998). The fatty acid profile was analyzed with Gas Chromatography (GC) (Chromatograph HP 5890 Series II gas chromatograph) coupled to a flame ionization detector (FID) (METCALFE; SCHMITZ, 1961) according to following parameters: helium was used as the carrier gas at a flow rate of $1 \mathrm{~mL}$ $\mathrm{min}^{-1}$; the column temperature was programmed at $180{ }^{\circ} \mathrm{C}$ ramping to $240{ }^{\circ} \mathrm{C}$ at $0.5^{\circ} \mathrm{C} \mathrm{min}^{-1}$ and then to $270{ }^{\circ} \mathrm{C}$ at $10^{\circ} \mathrm{C} \mathrm{min}^{-1}$, followed by a hold at 290 ${ }^{\circ} \mathrm{C}$ for $10 \mathrm{~min}$; the injector temperature was $240{ }^{\circ} \mathrm{C}$ and detector temperature was $280^{\circ} \mathrm{C}$. FAME (fatty acid methyl esters mixture) was identified using C14-22 (Sigma-Aldrich) as calibration mix.

Table 2. $\mathrm{N}$ doses in urea form $\left(\mathrm{kg} \mathrm{ha}^{-1}\right)$ were applied to the Neon, Catissol 01 and BRS324 sunflower cultivars, at planting and $30 \mathrm{DAE}$.

\begin{tabular}{llll}
\hline & \multicolumn{3}{c}{$\begin{array}{c}\text { N doses in urea form } \\
\left(\mathrm{kg} \mathrm{ha}^{-1}\right)\end{array}$} \\
\cline { 2 - 4 } Treatments & Planting & $30 \mathrm{DAE}^{*}$ & Total \\
\hline 1 & 0 & 0 & 0 \\
2 & 10 & 0 & 10
\end{tabular}


3

4

5

6
10

10

10

10
20

40

80

120
30

50

90

130

*DAE: Days after emergence

\section{RESULTS AND DISCUSSION}

In the three evaluated genotypes, the accumulation of nutrients $\left(\mathrm{N}-\mathrm{NO}_{3}^{-}\right)$was influenced by the increase of $\mathrm{N}$ doses, being Catissol 01 apparently the most efficient (Figure 1). Some studies show that the levels of $\mathrm{N}^{-\mathrm{NO}_{3}}{ }^{-}$in sunflower petiols are higher in the bud sprouting, but accumulates in the stem as the flowering stage for grain filling advances, which explains the absence of significant nutrients on leaf blades (ALVES et al., 2016).
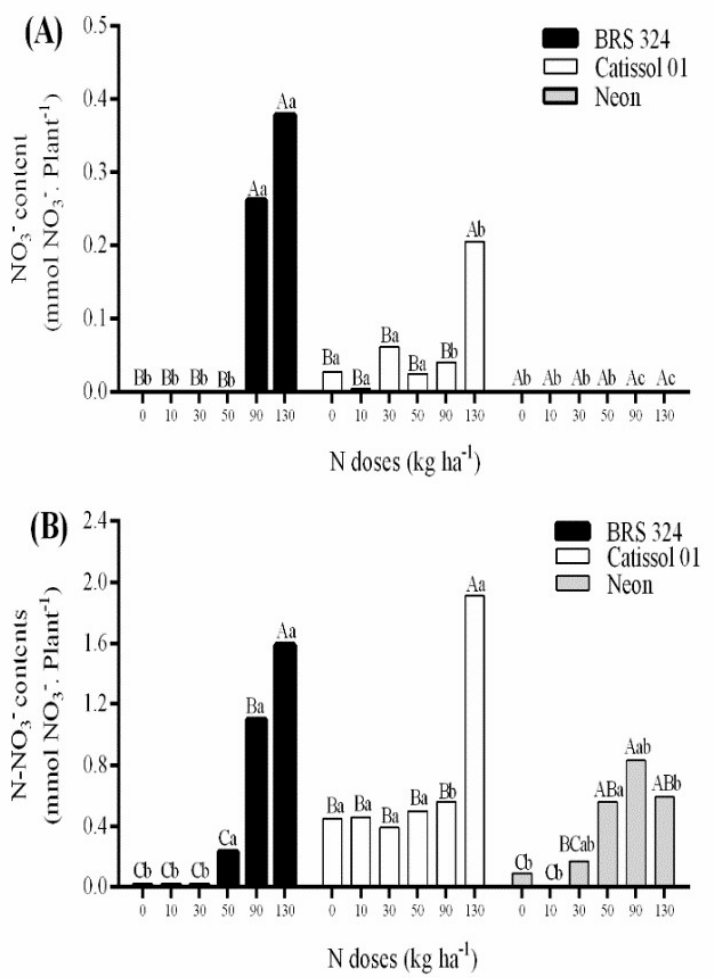

Figure 1. ${\mathrm{N}-\mathrm{NO}_{3}}^{-}$content in petiole (A) and stem (B) of cultivars BRS324, Catissol 01 and Neon grown under different doses of $\mathrm{N}$ and collected at flowering (stage R5).

Capital letters compare means between doses in the same genotype; lowercase letters compare means between different genotypes; Means followed by the same letter do not differ according to Tukey's test $(p \leq 0.05)$.

No significant differences regarding to $\mathrm{N}$ $\mathrm{NH}_{4}{ }^{+}$content for the Catissol 01 and BRS324 cultivars in the treatments with 10 and $130 \mathrm{~kg} \mathrm{~N}^{-1}$ were observed (Figure 2A). Catissol 01 presented the lowest $\mathrm{N}-\mathrm{NH}_{4}^{+}$contents in all treatments (Figures 2A, B and C), indicating high potential for $\mathrm{N}$ storage as $\mathrm{NO}_{3}^{-}$. The highest content was contained in the stem.
A positive correlation between $\mathrm{NO}_{3}^{-}$and $\mathrm{NH}_{4}{ }^{+}$in the stem of BRS324 $\left(\mathrm{R}^{2}=0.65\right)$ was detected (Figure $3 \mathrm{~A}$ ). These values indicate that this genotype absorbed and stored nitrate in the stem vacuoles in the same intensity as the ammonium used. According to Santos and Fernandes (2005), only after $\mathrm{N}$ becomes unavailable to the plant is $\mathrm{NO}_{3}^{-}$stored in vacuoles remobilized to supply $\mathrm{N}$ requirements. 


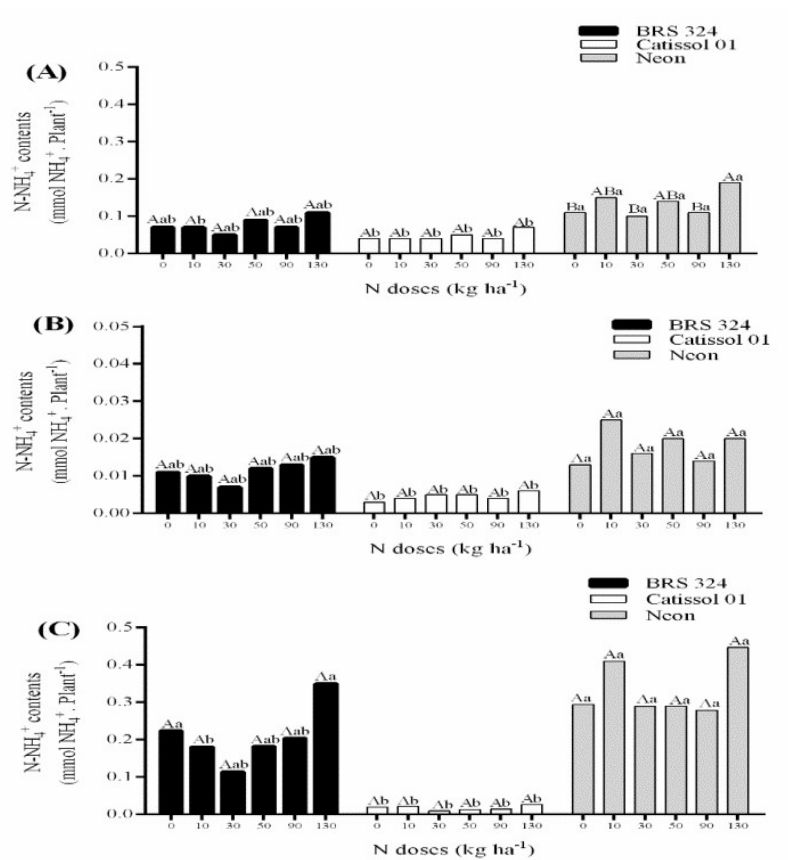

Figure 2. $\mathrm{N}-\mathrm{NH} 4^{+}$content in leaf blade (A), petiole (B) and stem (C) of cultivars BRS324, Catissol 01 and Neon cultivated under different doses of $\mathrm{N}$ and collected at flowering (stage R5).

Capital letters compare means between doses in the same genotype; lowercase letters compare means between doses of different genotypes; The means followed by the same letter do not differ according to the Tukey test $(p \leq 0.05)$.
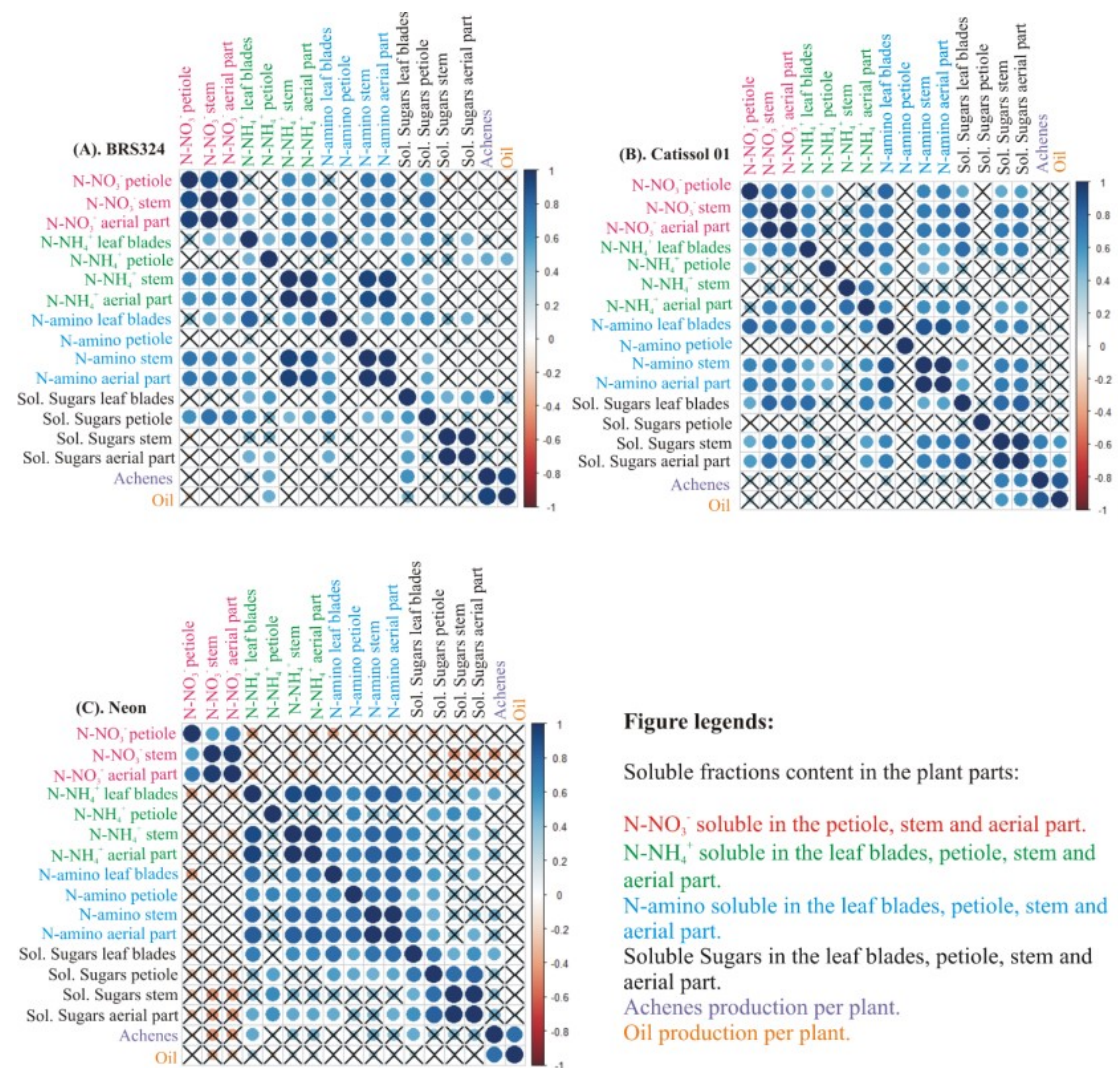

Figure 3. Graphic visualization of the Pearson correlation matrix of the soluble fraction contents analyzed in the leaf blade, petiole, stem and aerial part, and also achene production per plant and oil production of sunflower cultivars (BRS324, Catissol 01 and Neon), grown with different doses of $\mathrm{N}$ in urea form $\left(0,10,30,50,90,130 \mathrm{~kg} \mathrm{~N} . \mathrm{ha}^{-1}\right)$.

The blue circles denote positive correlation and the red circles negative correlation (significant at $\mathrm{p}<0.05$ ). The circles marked with $\mathrm{X}$ represent statistically non-significant correlations. 
In leaf blades, the Neon genotype presented the highest $\mathrm{N}$-amino in treatments 10 and $130 \mathrm{~kg} \mathrm{~N}$ $\mathrm{ha}^{-1}$ (Figure 4A). In all sunflower genotypes, the major site of soluble $\mathrm{N}$-amino accumulation occurred in the stem at a dose of $130 \mathrm{~kg} \mathrm{~N} \mathrm{ha}^{-1}$ (Figure 4C). According to Scheible et al. (1997), the availability of $\mathrm{NO}_{3}^{-}$in soil may provide higher
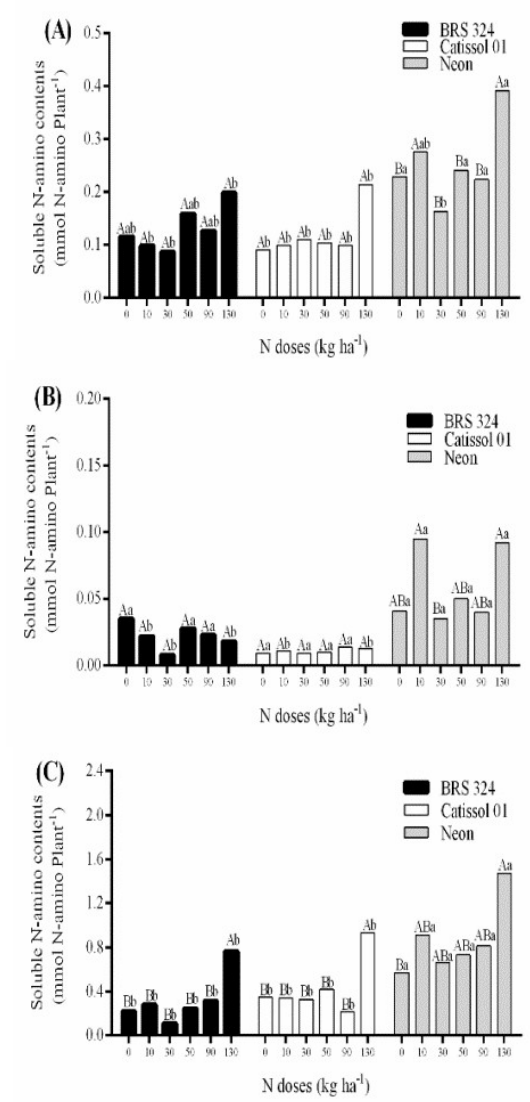

Figure 4. N-amino content in leaf blade (A), petiole (B) and stem (C) of cultivars BRS324, Catissol 01 and Neon cultivated under different doses of $\mathrm{N}$ and collected at flowering (stage R5).

Capital letters compare means between doses in the same genotype; lowercase letters compare means between doses of different genotypes; The means followed by the same letter do not differ according to the Tukey test $(\mathrm{p} \leq 0.05)$.

Regarding soluble N-amino content related to $\mathrm{N}^{-\mathrm{NH}_{4}}{ }^{+}$, positive correlations in the leaf blade $\left(\mathrm{R}^{2}\right.$ $=0.83 ; 0.75)$ and stem $\left(\mathrm{R}^{2}=0.95 ; 0.82\right)$ were observed for the BRS324 and Neon cultivars, respectively (Figures $3 \mathrm{~A}$ and $3 \mathrm{C}$ ). This might be due to a balance between the absorbed ions and the incorporated ones in existing carbon skeletons, possibly employed in synthesis of several amino acids as well. In addition, correlation between Namino and nitrate presented high values in the stem for BRS324 $\left(\mathrm{R}^{2}=0.72\right)$ and Catissol $01\left(\mathrm{R}^{2}=0.71\right)$ (Figure 3A and 3B). According to Santos et al. (2009), high free $\mathrm{N}$-amino doses can contribute to $\mathrm{NO}_{3}^{-}$accumulation in plant tissues, since some studies have demonstrated that $\mathrm{NO}_{3}^{-}$and its reduction products influence its acquisition and assimilation.
The highest soluble sugars content was observed in the stem in all cultivars (Figure 5), so this compartment was main energy source for plant metabolism reactions. Rocha et al. (2014), analyzing hydroponic cultivation of the BRS324 genotype, observed similar results. Soluble sugars content in the leaf blade of the Neon genotype among doses were significantly different, and the highest accumulated sugar percentages were observed at the highest doses. On the other hand, Catissol 01 and BRS324 presented the lowest sugar content (Figure $5)$.

Positive correlations between free $\mathrm{N}$-amino and soluble sugars in the leaf blade of BRS324, Catissol 01 and Neon cultivars $\left(\mathrm{R}^{2}=0.76 ; 0.70\right.$; 0.72 ), respectively, were observed (Figures 3A, 3B and $3 \mathrm{C}$ ). This result indicated that $\mathrm{N}$-amino content increases with soluble sugars due to $\mathrm{N}$ availability to 
plants, and might be associated with remobilization of stored $\mathrm{NO}_{3}^{-}$. A positive correlation between soluble sugars content in the aerial part and oil production $\left(\mathrm{R}^{2}=0.61\right)$ for Catissol 01 was also observed (Figure 3B). This result indicates the highest availability of carbon skeletons in this compartment, corresponding to increased oil production.

Significant correlations were positive, corroborating soil $\mathrm{N}$ availability to the plant, as well as indicating that these plants were still absorbing and storing nutrients with no metabolism reduction.

According to Castro and Farias (2005), sunflower plants from flower bud formation to the end of flowering grow faster and absorb higher levels of nutrients.

Leaf blades showed the highest N-total content for all cultivars (Table 3) at the R5 stage, indicating high metabolic activity and protein concentration, as for example, the RuBisCO, one occurring in great quantity in this tissue from $\mathrm{C} 3$ plants (PARRY et 1., 2013).

The highest $\mathrm{N}$-total content in the capitulum was observed at the highest $\mathrm{N}$ dose $\left(130 \mathrm{~kg} \mathrm{~N} \mathrm{ha}^{-1}\right)$ for the Neon and Catissol 01 cultivars, while for BRS324 no significant differences were noted (Table 3).

The highest N-total content in the stem of Catissol 01 was observed at $130 \mathrm{~kg} \mathrm{~N} \mathrm{ha}^{-1}$ dose, compared to the other treatments and cultivars during the R5 stage (Table 3). The higher $\mathrm{N}^{-\mathrm{NO}_{3}}{ }^{-}$ (Figure 1) and $\mathrm{N}$-amino (Figure 4) were also influenced by the higher dose in this genotype.
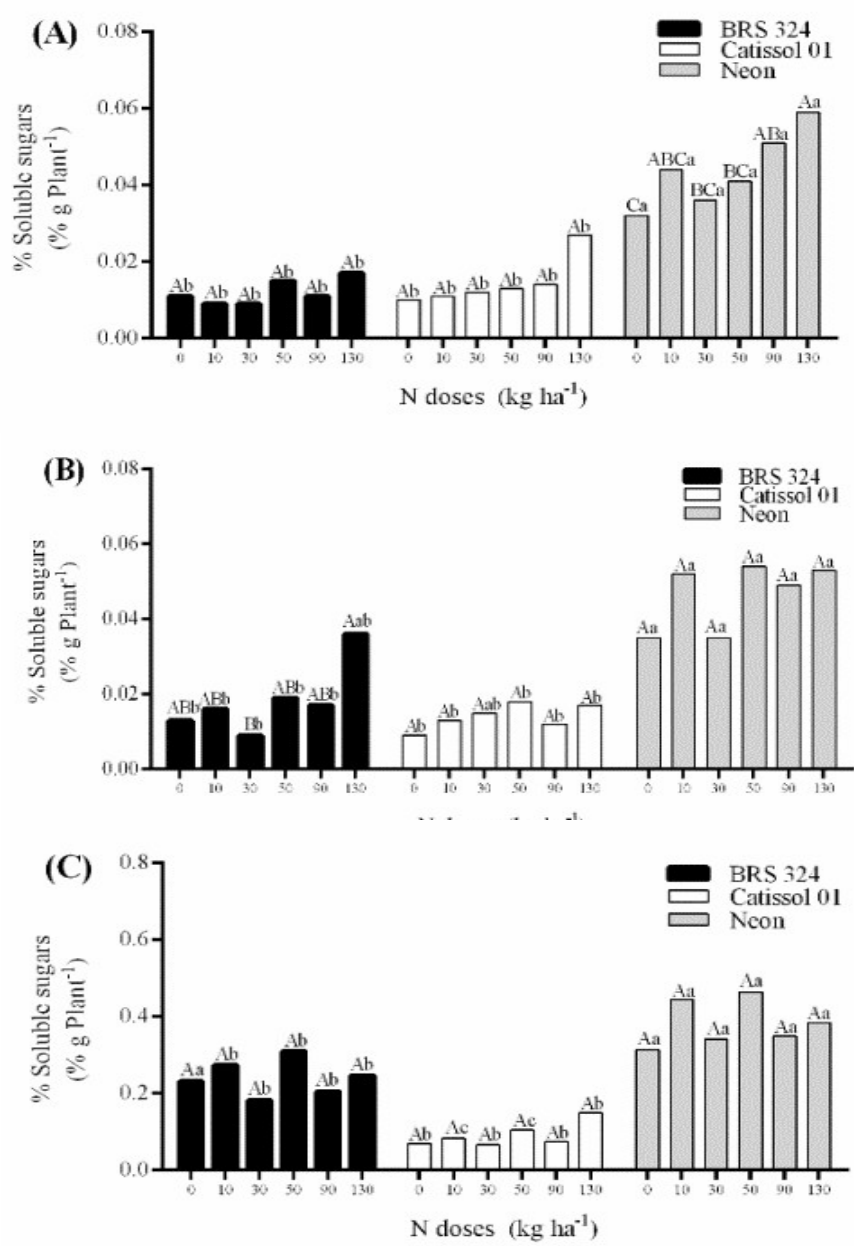

Figure 5. Soluble sugars percentages in the leaf blade (A), petiole (B) and stem (C) of cultivars BRS324, Catissol 01 and Neon cultivated under different doses of $\mathrm{N}$ and collected at flowering (stage R5).

Capital letters compare means between doses in the same genotype; lowercase letters compare means between doses of different genotypes; The means followed by the same letter do not differ according to the Tukey test $(p \leq 0.05)$. 
Table 3. N-total content (mg dry plant ${ }^{-1}$ ) in the leaf blade, capitulum, petiole and stem of sunflower plants of three cultivars (BRS324, Catissol 01 and Neon) cultivated in the field at flowering (R5 stage) and submitted to increasing $\mathrm{N}$ doses in urea form.

\begin{tabular}{|c|c|c|c|c|c|c|c|c|c|c|c|c|}
\hline \multirow{3}{*}{ Treat. } & \multicolumn{12}{|c|}{ N-TOTAL } \\
\hline & \multicolumn{6}{|c|}{ LEAF BLADE } & \multicolumn{6}{|c|}{ CAPITULUM } \\
\hline & \multicolumn{2}{|c|}{ BRS324 } & \multicolumn{2}{|c|}{ Catissol 01} & \multicolumn{2}{|c|}{ Neon } & \multicolumn{2}{|c|}{ BRS324 } & \multicolumn{2}{|c|}{ Catissol 01} & \multicolumn{2}{|c|}{ Neon } \\
\hline 0 & 495.49 & Aa & 498.50 & Aa & 633.22 & Aa & 304.52 & Aa & 325.80 & $\mathbf{B a}$ & 247.17 & Ba \\
\hline 10 & 498.45 & Aab & 423.36 & $\mathbf{A b}$ & 679.09 & Aa & 266.59 & Aa & 344.86 & $\mathbf{B a}$ & 253.44 & $\mathbf{B a}$ \\
\hline 30 & 380.82 & $\mathbf{A b}$ & 383.59 & $\mathbf{A b}$ & 626.72 & Aa & 296.46 & Aa & 270.73 & $\mathbf{B a}$ & 298.18 & $\mathbf{B a}$ \\
\hline 50 & 593.82 & Aab & 414.50 & $\mathbf{A b}$ & 668.55 & Aa & 412.26 & Aa & 300.25 & Ba & 280.58 & Ba \\
\hline 90 & 418.48 & $\mathbf{A b}$ & 408.32 & $\mathbf{A b}$ & 843.69 & Aa & 384.68 & Aa & 308.12 & Ba & 281.09 & $\mathbf{B a}$ \\
\hline 130 & 565.87 & $\mathbf{A b}$ & 523.91 & $\mathbf{A b}$ & 796.40 & Aa & 395.92 & $\mathbf{A b}$ & 567.96 & Aa & 427.72 & Aab \\
\hline Average & 492.16 & & 442.03 & & 707.95 & & 343.41 & & 352.95 & & 298.03 & \\
\hline \multirow{3}{*}{$\begin{array}{l}\text { CV\% } \\
\text { Treat. }\end{array}$} & \multicolumn{6}{|c|}{20.28} & \multicolumn{6}{|c|}{38.85} \\
\hline & \multicolumn{6}{|c|}{ PETIOLE } & \multicolumn{6}{|c|}{ STEM } \\
\hline & \multicolumn{2}{|c|}{ BRS324 } & \multicolumn{2}{|c|}{ Catissol 01} & \multicolumn{2}{|c|}{ Neon } & \multicolumn{2}{|c|}{ BRS324 } & \multicolumn{2}{|c|}{ Catissol 01} & \multicolumn{2}{|c|}{ Neon } \\
\hline 0 & 15.86 & Bb & 16.26 & Bb & 37.78 & $\mathbf{B a}$ & 225.74 & Aa & 204.71 & $\mathbf{B a}$ & 313.09 & $\mathbf{A a}$ \\
\hline 10 & 25.40 & $\mathbf{A B b}$ & 24.00 & Bab & 45.40 & $\mathbf{B a}$ & 272.08 & Aa & 203.64 & $\mathbf{B a}$ & 265.90 & $\mathbf{A a}$ \\
\hline 30 & 13.64 & Bb & 15.63 & $\mathbf{A B b}$ & 56.77 & $\mathbf{A B a}$ & 200.40 & Aa & 141.69 & $\mathbf{B a}$ & 269.53 & Aa \\
\hline 50 & 31.32 & $\mathbf{A B b}$ & 24.88 & $\mathbf{A B b}$ & 70.07 & Aa & 251.63 & Aab & 212.35 & $\mathbf{B b}$ & 351.23 & Aa \\
\hline 90 & 25.39 & $\mathbf{A B b}$ & 26.92 & Bb & 65.11 & ABa & 223.47 & Aab & 180.14 & Bb & 317.34 & Aa \\
\hline 130 & 43.71 & Aa & 40.20 & Aa & 72.80 & Aa & 200.41 & $\mathbf{A b}$ & 446.38 & Aa & 270.48 & $\mathbf{A b}$ \\
\hline Average & 25.89 & & 24.65 & & 57.99 & & 228.96 & & 231.49 & & 297.93 & \\
\hline CV\% & & & 26.31 & & & & & & 22.61 & & & \\
\hline
\end{tabular}

Vertical capital letters compare means between doses in the same genotype; horizontal lowercase letters compare means between different genotypes; The means followed by the same letter do not differ according to the Tukey test $(\mathrm{p} \leq 0.05)$.

The Neon genotype presented the highest achenes production and had productivity reduction in the highest doses with nitrogen fertilization, the production peak occurred at $80 \mathrm{~kg}$ of $\mathrm{N} \mathrm{ha}^{-1}$ (Figure 6 ). The yield was over $4000 \mathrm{~kg} \mathrm{ha}^{-1}$, higher than reported by Oliveira et al. (2009) in sunflower experiments in Rio Grande do Sul. Comparative studies by Alves (2014), also observed higher production for Neon, under low nitrogen fertilization. Therefore, the Neon genotype shows high grain yield capacity with low nitrogen fertilizer requirements.

For BRS324, application up to $50 \mathrm{~kg} \mathrm{~N} \mathrm{ha}^{-1}$ resulted in rising achene production, followed by significant decreases at higher doses (Figure 6). According to Biscaro et al. (2008), the best productivity for the Dekalb H358 sunflower genotype grown in Cassilandia, Mato Grasso do Sul, occurred with application of $55 \mathrm{~kg} \mathrm{ha}^{-1}$ of $\mathrm{N}$.

According to Smiderle (2009), sunflower grain yield can exceed $2,500 \mathrm{~kg} \mathrm{ha}^{-1}$ using currently available technologies. In experimental areas, yields above $3,000 \mathrm{~kg} \mathrm{ha}^{-1}$ were recorded (OLIVEIRA et al., 2008). We obtained satisfactory results from the three cultivars, all of which produced more than $3,000 \mathrm{~kg} \mathrm{ha}^{-1}$ in some treatments (Figure 6). According to Biscaro et al. (2008), nitrogen cover fertilization increased the production in comparison with no $\mathrm{N}$ treatment, so $\mathrm{N}$ fertilization is a practice with good return to growers if properly applied at the right time.

Regarding the oil production among the cultivars (Figure 7), large variation in production was observed according to the supply of N. The Neon genotype, despite surpassing the others regarding achene production (Figure 6), did not have high oil yield. This can be explained by a dilution effect, in which the increase in the grain production resulted in lower oil quantity per grain. This effect makes it more favorable for growers to plant this genotype for grain production rather than oil extraction, since oil production requires solvent costs. The other two cultivars did not present any dilution effect. 


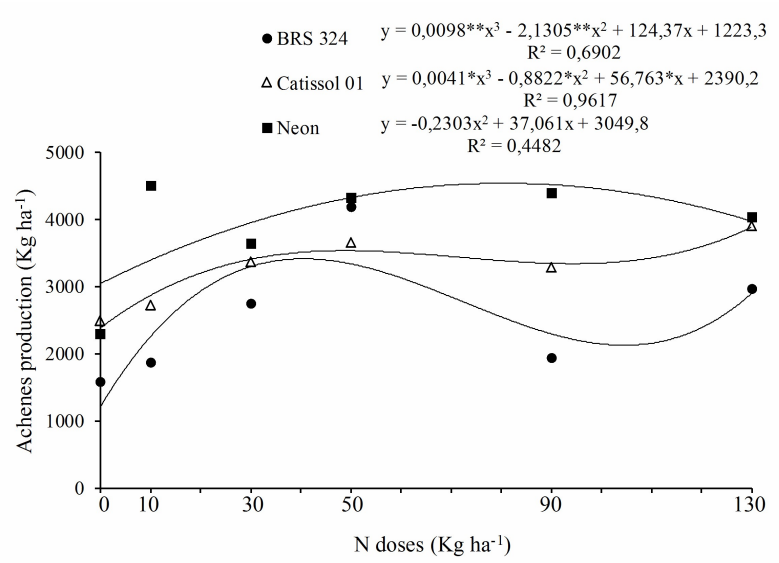

Figure 6. Achene production $\left(\mathrm{kg} \mathrm{ha}^{-1}\right)$ from sunflower cultivars (BRS324, Catissol 01 and Neon) with increasing urea doses $\left(0,10,30,50,90,130 \mathrm{Kg} \mathrm{N} \mathrm{ha}^{-1}\right)$ applied at planting and 30 days after germination (DAE).

** and *: respectively significant at $1 \%$, and $5 \%$ probability.

The fact that oil production has not increased when higher $\mathrm{N}$ dose is applied might be in the reason of the plant is diverting the $\mathrm{N}$ to other metabolic pathways and investing for obtaining biomass, as well. For all three cultivars evaluated, there was a decrease in oil production in plants under high nitrogen fertilization. Some studies carried out with several sunflower cultivars, have shown reductive effects on oil production when grown under high doses of nitrogen fertilizers (ABDEL-MOTAGALLY; OSMAN, 2010; RASOOL; HASSAN; JAHANGIR, 2013).
The BRS324 genotype presented the highest oil production with low nitrogen fertilization $(50 \mathrm{~kg}$ $\mathrm{N} \mathrm{ha}^{-1}$ ) when compared to the other ones (Figure 7). On the other hand, the Catissol 01 genotype presented the lowest grain yield, however, with high oil production, standing out as a promising genotype for oil extraction, characteristically with lower grains production, but with high oil yield, favoring the saving of solvents used the in extractive processes. Lobo, Grassi Filho and Coelho (2012) analyzing nitrogen fertilization effect on sunflower productivity also observed that with increasing $\mathrm{N}$ dose there is a decrease in grains oil content.

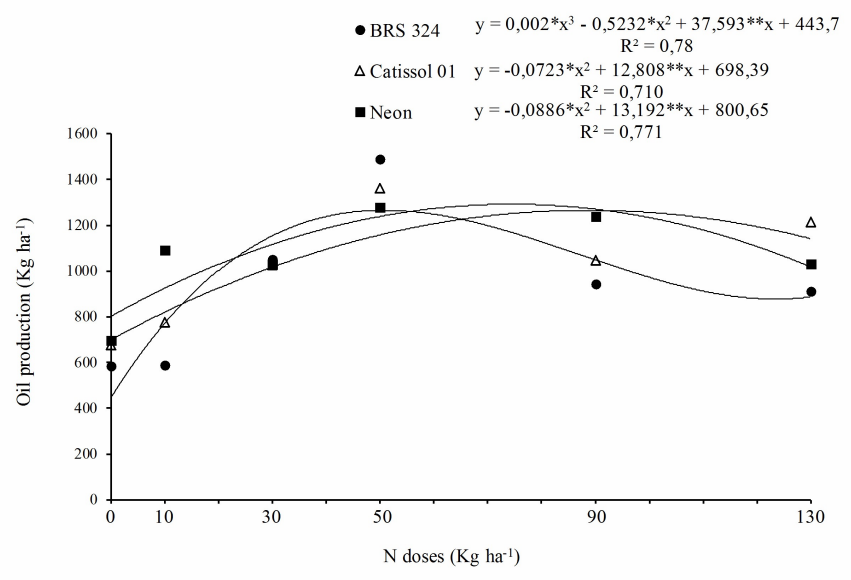

Figure 7. Extracted oil quantity from sunflower seeds (the BRS324, the Catissol 01 and the Neon) cultivated with increasing urea doses $\left(0,10,30,50,90,130 \mathrm{~kg} \mathrm{~N} \mathrm{ha}^{-1}\right)$ applied at planting and in the field at 30 days after emergence (DAE).

$* *$ and *: respectively significant at $1 \%$, and $5 \%$ probability.

While conducting the experimental work, high climatic temperatures were recorded the plant's reproductive period (Figure 8), which may have influenced qualitative characteristics in the composition of oil extracted from the genotypes. Profile analyzes show high levels of fatty acids for oleic and linoleic peaks with higher proportions of oleic acid than linoleic (Figure 9 e 10). The direct 
relationship of environmental factors, such as high temperature, affects achenes production and may influence the chemical composition of vegetable oil during grain development (OLIVEIRA; VIEIRA 2004).

High oil yield is important for producing fuel. In this context, the fatty acid profile is crucial to know if the oil is suitable for biodiesel production. According to Knothe (2008), the methyl esters from oleic acid positively influence biodiesel quality, since among its effects is to raise the cetane number and the fuel oxidative stability. The variation in fatty acid composition results in oil production for different purposes. For biofuel, the employment of unsaturated fatty acids oil is preferable because the presence of unsaturated chains reduces biodiesel solidification. However, the presence of fatty acids with four or more unsaturations can result in oxidation (DABDOUB; BRONZEL; RAMPIN, 2009).

No statistical models were reported with significant differences between $\mathrm{N}$ doses and oleic acids of cultivars (Figure 9). However, the difference between BRS324 and the other two cultivars comparing the mean $\mathrm{N}$ doses can be emphasized. The BRS324 genotype presented lower oleic acid content at $130 \mathrm{~kg} \mathrm{~N}$ ha $^{-1}$ (Figure 9). However, for linoleic acid, the Neon cultivar presented significantly higher levels at doses of 30 and $50 \mathrm{~kg} \mathrm{ha}^{-1}$ compared to the other two cultivars, with a significant reduction for the linear model, as $\mathrm{N}$ doses increased was also seen in cultivar BRS324 from the $30 \mathrm{~kg} \mathrm{~N} \mathrm{ha}^{-1}$ dose, with a significant linear increase at C14: 00 as the $\mathrm{N}$ doses increased (Figures 9 and 10). This effect may be associated evidence with the enzymatic activities of FAD2 desaturase (fatty acid desaturase 2), which transforms polyunsaturated acids into saturated acids (WANG et al., 2018; TANG et al., 2005).

Thus, we can determine that the excess nitrogen supplied to the plant contributed to the disruption of unsaturated molecules and increased saturated acid content for this genotype. without $\mathrm{N}$ application (zero dose), BRS324 and Neon produced significantly more linoleic acid than the Catissol 01 genotype. The fatty acids myristic, palmitic and linolenic fatty acids had a lower percentage than oleic and linoleic fatty acids (Figure 9) little contribution to biodiesel production.

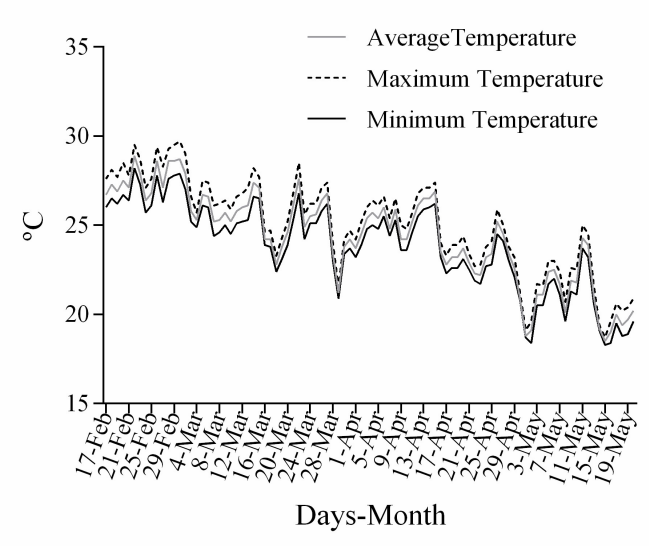

Figure 8. Maximum, minimum and average temperatures $\left({ }^{\circ} \mathrm{C}\right)$ during cultivation period of the BRS324, Catissol 01 and Neon sunflower cultivars in the field (from February 17 to May 20, 2012). Source: INMET - Automatic Meteorological Station of Ecologia Agrícola. RJ. 

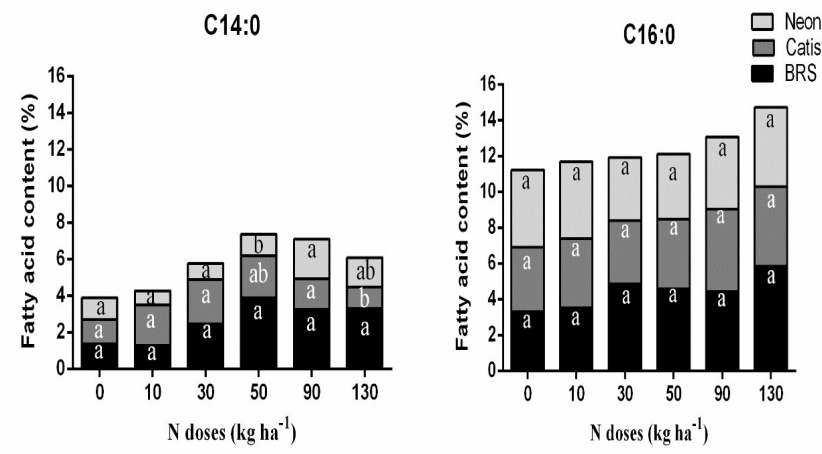

C18:1


C18:3

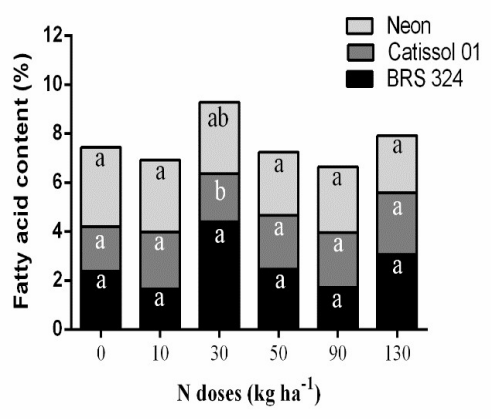

Figure 9. Amount of fatty acids produced and the sunflower cultivars for each ammonium dose $(0,10,30,50$, 90, $130 \mathrm{Kg} \mathrm{N}$ ha-1) applied 30 days after field emergence, achene collected at the end of maturation. Fatty acids: (C14:0 - Myristic; C16:0 - Palmitic; C18:1- Oleic; C18:2 - Linoleic; C18:3 - Linolenic). The means followed by the same letter in the bar do not differ according to the Tukey test $(\mathrm{p} \leq 0.05)$. 



Figure 10. Fatty acids quantified in the oil profile extracted from seeds of sunflower genotypes BRS324, Catissol 01 and Neon submitted to increasing doses of urea $(0,10,30,50,90,130 \mathrm{~kg} \mathrm{~N}$ ha-1) applied at 30 days planting. after germination.

$* *, *$ and ns: respectively significant at $1 \%, 5 \%$ and not significant.

\section{CONCLUSIONS}

The stem accumulated the highest $\mathrm{NO}_{3}{ }^{-}$ concentration, with emphasis on the Catissol 01 cultivar that accumulated the largest amounts, and is indicative of adaptation of this cultivar to the storage of $\mathrm{N}$.

Neon showed higher achenes production compared to other cultivars. However, the BRS324 cultivar produced the highest oil content per hectare with the lowest nitrogen fertilization dose. Suitable doses for oil production were 30 to $50 \mathrm{~kg} \mathrm{~N} \mathrm{ha}^{-1}$.
Regarding the oil profile for the biodiesel industry, oleic fatty acid showed satisfactory performance in all three cultivars analyzed. BRS324 cultivar had reduced production when the highest $\mathrm{N}$ dose was applied.

Supplementation with nitrogen fertilizer in doses above $30 \mathrm{~kg}$ of $\mathrm{N}$ ha-1 contributed to a reduction in linoleic acid and an increase in C14: 0 fatty acid. The results suggest that among the evaluated cultivars, Catissol 01 is more economically suitable for the production of biofuel oil when cultivated at $50 \mathrm{~kg} \mathrm{~N} \mathrm{ha}^{-1}$, since high $\mathrm{N}$ 
rates did not increase oil production. Therefore being an adaptive method and economic advantage in that less input would also be spent.

\section{ACKNOWLEDGMENTS}

We are grateful to Petrobras Biocombustível (Petro Bio Girassol) and Coordenação de Aperfeiçoamento de Pessoal de Nível Superior Brasil (CAPES) - Finance Code 001.

RESUMO: O girassol é uma espécie com importante valor econômico pela qualidade e rendimento de óleo. Entre os fatores que influenciam esses parâmetros se destaca a fertilização nitrogenada. Este trabalho avaliou o efeito de doses crescentes de $\mathrm{N}$-uréia $\left(0,10,30,50,90,130 \mathrm{~kg}^{\mathrm{de}} \mathrm{N}\right.$-Uréia ha ${ }^{-1}$ aplicadas no plantio e aos 30 dias após a emergência) sobre as frações solúveis, rendimento e perfil do óleo de três genótipos de girassol (BRS324, Neon e Catissol 01). As plantas foram coletadas no estádio de floração para o estudo metabólico e ao final do ciclo para a extração e caracterização de óleo. O genótipo Catissol 01 apresentou maior capacidade de acúmulo de $\mathrm{N}_{-} \mathrm{NO}_{3}{ }^{-}$, preferencialmente no caule. A maior produção de óleo por planta foi observada no BRS324, nas doses entre 30 e $50 \mathrm{~kg} \mathrm{~N} \mathrm{ha}^{-1}$, embora o genótipo Neon tenha apresentado a maior produção de aquênios. O ácido oléico foi o de maior rendimento com destaque para os genótipos Catissol $01 \mathrm{e}$ Neon. Dentre os genótipos avaliados, o Catissol 01 é economicamente mais indicado para a produção de óleo destinada ao biocombustível, quando cultivado com a dose de $50 \mathrm{~kg} \mathrm{~N} \mathrm{ha}^{-1}$, pois doses superiores de $\mathrm{N}$ não resultam em aumento na produção de óleo.

PALAVRAS-CHAVE: Biodiesel. Helianthus annuus L. Oleaginosa.

\section{REFERENCES}

ABDEL-MOTAGALLY, F. M. F.; OSMAN, E. A. Effect of nitrogen and potassium fertilization combinations on productivity of two sunflower cultivars under East of El-ewinate conditions. American-Eurasian Journal of Agricultural and Environmental Science, Pakistan, v. 8, n. 4, p. 397-401, 2010.

ALVES, L. S. Cinética de absorção de nitrato e amônio e produção de grãos e óleo de girassol em diferentes níveis de nitrogênio e boro. Dissertação (Mestrado em Agronomia, Ciência do Solo) - Curso de Pós-Graduação em Agronomia-Ciência do Solo, Universidade Federal Rural do Rio de Janeiro, Seropédica, RJ, 2014.

ALVES, L. S.; TORRES JUNIOR, C. V.; FERNANDES, M. S.; SANTOS, A. M.; SOUZA, S. R. Soluble fractions and kinetics parameters of nitrate and ammonium uptake in sunflower ("Neon" Hybrid). Revista Ciência Agronômica, Fortaleza, v. 47, n. 1, p. 13-21, 2016. http://dx.doi.org/10.5935/1806-6690.20160002

BISCARO, G. A.; MACHADO, J. R.; TOSTA, M. D. S.; MENDONÇA, V.; SORATTO, R. P.; CARVALHO, L. A. Adubação nitrogenada em cobertura no girassol irrigado nas condições de Cassilândia-MS. Ciência e Agrotecnologia, Lavras, v. 32, n. 5, p. 1366-1373, 2008. http://dx.doi.org/10.1590/S1413$\underline{70542008000500002}$

CATALDO, D. A.; MAROON, M.; SCHRADER, L. E.; YOUNGS, V. L. Rapid colorimetric determination of nitrate in plant tissue by nitration of salicylic acid. Communications in soil science and plant analysis, Philadelphia, v. 6, n. 1, p. 71-80, 1975. https://doi.org/10.1080/00103627509366547

DABDOUB, M. J.; BRONZEL, J. L.; RAMPIN, M. A. Biodiesel: visão crítica do status atual e perspectivas na academia e na indústria. Química Nova, São Paulo, v. 32, n. 3, p. 776-792, 2009.

http://dx.doi.org/10.1590/S0100-40422009000300021

FELKER, P. Microdetermination of nitrogen in seed protein extracts with the salicylate-dichloroisocyanurate color reaction. Analytical Chemistry, Whashington, v. 49, n. 7, p. 1080-1080, 1977.

https://doi.org/10.1021/ac50015a053 
LAZZAROTTO, J. J.; ROESSING, A. C.; MELLO, A. C. Agronegócio do girassol no mundo e no Brasil. In: LEITE, R. M. V. B. C.; BRIGHENTI, A. M.; CASTRO, C. (Ed.). Girassol no Brasil. Londrina: Embrapa soja, 2005.

KNOTHE, G. Designer" biodiesel: optimizing fatty ester composition to improve fuel properties. Energy \& Fuels, Whashington, v. 22, n. 2, p. 1358-1364, 2008. https://doi.org/10.1021/ef700639e

LOBO, T. F.; GRASSI FILHO, H.; COELHO, H. A. Efeito da adubação nitrogenada na produtividade do girassol. Científica, Jaboticabal, v. 40, n. 1, p. 59-68, 2012. http://dx.doi.org/10.15361/1984$\underline{5529.2012 \mathrm{v} 40 \mathrm{n} 1 \mathrm{p} 59-68}$

MATT, P.; GEIGER, M.; WALCH-LIU, P.; ENGELS, C.; KRAPP, A.; STITT, M. The immediate cause of the diurnal changes of nitrogen metabolism in leaves of nitrate-replete tobacco: a major imbalance between the rate of nitrate reduction and the rates of nitrate uptake and ammonium metabolism during the first part of the light

period. Plant, Cell \& Environment, Amsterdam, v. 24, n. 2, p. 177-190, 2001. https://doi.org/10.1111/j.1365$\underline{3040.2001 .00676 . \mathrm{X}}$

METCALFE, L. D.; SCHMITZ, A. A. The rapid preparation of fatty acid esters for gas chromatographic analysis. Analytical Chemistry, Whashington, v. 33, n. 3, p. 363-364, 1961.

https://doi.org/10.1021/ac60171a016

OLIVEIRA, M. F., VIEIRA, O. V. Extração de óleo de girassol utilizando miniprensa. Londrina: Embrapa Soja (Documentos 237), 2004. 27p. Available from:

http://www.infoteca.cnptia.embrapa.br/infoteca/handle/doc/457158

OLIVEIRA, I. R.; CARVALHO, H. W. L.; CARVALHO, C. G. P.; MELO, K. E.; FEITOSA, L. F.; MENEZES, A. F. Avaliação de cultivares de girassol no Estado de Sergipe. Aracaju: Embrapa Tabuleiros Costeiros (Circular Técnica, 53), 2008. Available from:

http://www.infoteca.cnptia.embrapa.br/infoteca/handle/doc/471124

OLIVEIRA, A. C. B.; CARVALHO, C. G. P; EMYGDIO, M. B.; GRUNVALD, A. K. Avaliação de Genótipos de Girassol no RS. Boa Vista: Embrapa Clima Temperado (Circular técnica, 89), 2009. Available from: http://www.infoteca.cnptia.embrapa.br/infoteca/handle/doc/748227

RAMOS, L. P.; KUCEK, K. T.; DOMINGOS, A. K.; WILHELM, H. M. Biodiesel - Um projeto de sustentabilidade econômica e sócio-ambiental para o Brasil. Revista Biotecnologia Ciência e

Desenvolvimento, Goiania, v. 31, p. 28-37, 2003.

RASOOL, F. U.; HASSAN, B.; JAHANGIR, A. Growth and yield of sunflower (Helianthus annus L.) as influenced by nitrogen, sulphur and farmyard manure under temperate conditions. SAARC Journal of Agriculture, Bangladesh, v. 11, n. 1, p. 81-89, 2013. https://doi.org/10.3329/sja.v11i1.18386

ROCHA, J. G.; FERREIRA, L. M.; TAVARES, O. C. H.; SANTOS, A. M.; SOUZA, S. R. Cinética de absorção de nitrogênio e acúmulo de frações solúveis nitrogenadas e açúcares em girassol. Pesquisa Agropecuária Tropical, Goiania, v. 44, n. 4, 2014. https://doi.org/10.1590/S1983-40632014000400009

SANTOS, L. A.; FERNANDES, M. S. Metabolismo de nitrogênio em arroz sob níveis decrescentes de nitrato. Agronomia, Rio de Janeiro, v. 39, n. 1-2, p. 28-33, 2005.

SANTOS, L. A.; BUCHER, C. A.; SOUZA, S. R.; FERNANDES, M.S. Effects of nitrogen stress on protonpumping and nitrogen metabolism in rice. Journal of Plant Nutrition, Philadelphia, v. 32, n. 4, p. 549-564, 2009. https://doi.org/10.1080/01904160802714953 
SCHEIBLE, W.; GONZÁLEZ-FONTES, A.; LAUERER, M.; MULLER-RONERT, B.; CABOCHE, M.; STITT, M. Nitrate acts as a signal to induce organic acid metabolism and repress starch metabolism in tobacco. The Plant Cell, Waterbury, v. 9, n. 5, p. 783-798, 1997. https://doi.org/10.1105/tpc.9.5.783

SKORIC, D.; SAKAC, Z.; DEMURIN, Y. Genetic variability of oil quality components in sunflower as a function of developing hybrids with novel oil. Plant Genetics and Breeding. Journal of ASM Life Sciences, Malaysia, v. 2, n. 326, p. 138-146, 2015.

SMIDERLE, O.J. Orientações Para Cultivo do Girassol em Área de Cerrado de Roraima. Boa Vista: Embrapa Roraima (Circular técnica, 05), 2009. Available from: https://www.embrapa.br/busca-depublicacoes/-/publicacao/696131/orientacoes-para-cultivo-do-girassol-em-area-de-cerrado-de-roraima

TANG, G. Q.; NOVITZKY, W. P.; CAROL GRIFFIN, H.; HUBER, S. C.; DEWEY, R. E. Oleate desaturase enzymes of soybean: evidence of regulation through differential stability and phosphorylation. The Plant Journal, London, v. 44, n. 3, p. 433-446, 2005. https://doi.org/10.1111/j.1365-313X.2005.02535.x

TEDESCO, J. M.; GIANELLO, C.; BISSANI, C. A.; BOHNEN, H.; VOLKWEISS, S. J. Análise de solo, plantas e outros materiais. 2a ed. Porto Alegre: UFRGS, 1995.

YANIV, Z.; SHABELSKY, E.; SCHAFFERMAN, D.; GRANOT, I.; KIPINIS, T. Oil and fatty acid changes in Sinapis and Crambe seeds during germination and early development. Industrial crops and Products, Amsterdam, v. 9, n. 1, p. 1-8, 1998. https://doi.org/10.1016/S0926-6690(98)00005-3

YEMM, E. W.; WILLIS, A. J. The estimation of carbohydrates in plant extracts by anthrone. Biochemical Journal, London, v. 57, n. 3, p. 508, 1954. https://doi.org/10.1042/bj0570508

YEMM, E. W.; COCKING E. C. The determination of amino-acid with ninhydrin. Analytical Biochemistry, San Diego, v. 80, p. 209-213, 1955. https://doi.org/10.1039/an9558000209

WANG, M. L.; CHEN, C. Y.; TONNIS, B.; PINNOW, D.; DAVIS, J.; AN, Y.; DANG, P. Changes of Seed Weight, Fatty Acid Composition, Oil and Protein Content from Different Peanut FAD2 Genotypes at Different Seed Developmental and Maturation Stages. Journal of Agricultural and Food Chemistry, Whashington, v. 66, n. 14, p. 3658-3665, 2018. https://doi.org/10.1021/acs.jafc.8b01238

WEI, T.; SIMKO, V. R package 'corrplot': visualization of a correlation matrix (version 0.84$)$. Vienna: $R$ Found. Stat. Comput, 2017. Available from: https://github.com/taiyun/corrplot

ZAGONEL, J.; MUNDSTOCK, C. M. Doses e épocas de aplicação de nitrogênio em cobertura em duas cultivares de girassol. Pesquisa Agropecuária Brasileira, Brasília, v. 26, n. 9, p. 1487-1492, 1991.

ZOBIOLE, L. H. S.; CASTRO, C.; OLIVEIRA, F. A.; OLIVEIRA JÚNIOR, A. Marcha de absorção de macronutrientes na cultura do girassol. Revista Brasileira de Ciência do Solo, Viçosa, v. 34, n. 2, 2010. http://dx.doi.org/10.1590/S0100-06832010000200016 